\title{
AN ANALYSIS OF THE CURRENT POLITICAL CRISIS IN FIJI
}

Teresia Teaiwa

The problem with Fijian nationalism is that there is no Fijian nation. There are Fijian provinces, and traditional Fijian confederacies, but the two military coups of 1987 and the current hostage crisis illustrate with disturbing insistence the erosion of indigenous Fijian social order and the fragmentation of indigenous Fijian leadership.

The problem with prevailing analyses of the political situation in Fiji is the notion that the conflict is between indigenous Fijians and Indo-Fijians. The 'race' card is misleading and mischievous, and unfortunately, Mahendra Chaudhry, Fiji's first Indo-Fijian Prime Minister, played right into it with his abrasive leadership style. But in the end, Chaudhry is not the problem and neither are the Indo-Fijian communities.

Fiji's problem is Fijian. Following the fortunes and misfortunes of the country's three indigenous Prime Ministers - Ratu Sir Kamisese Mara, Dr Timoci Bavadra, and Sitiveni Rabuka - we see the increasingly problematic configuration of indigenous leadership in the country.

Ratu Mara's leadership draws on the mana of his own chiefly title, Tui Nayau; his wife's mana (the Roko Tui Dreketi, from the confederacy of Burebasaga, is the highest chiefly title in the islands); and his close association with a tight elite cohort of European, part-European and IndoFijian business interests. Ratu Mara's leadership, however, has alienated rival chiefs, proletarian and nationalist groups within his domain of eastern Fiji, and has generated resentment in the western provinces. 
The late Dr Timoci Bavadra, Prime Minister in the predominantly IndoFijian Labour/National Federation Party coalition government, was consistently described in the media and literature as a 'commoner' even though he came from a noble Fijian background in the chiefly village of Viseisei. The problem with Dr. Bavadra's political genealogy in 1987 was not so much his Labour ideology nor his 'commoner' status, but the fact that significant and powerful sectors of indigenous Fijian society - in the east - were not ready for a Fijian Prime Minister from a western province.

Being both a 'commoner' and national leader clearly was not a problem for Sitiveni Rabuka. In fact, a large part of Rabuka's popularity with indigenous Fijians is his 'commoner' status. For indigenous Fijians Rabuka's mana comes from the interweaving of his traditional 'bati' or warrior genealogy (in the eastern province of Cakaudrove), his career in modern armed forces, his identification with and deployment of Christian/ Methodist discourse, his staging of the two coups d'état in 1987, and the support he has consistently received from the Great Council of Chiefs. Rabuka has even gained political mileage out of his 'human frailties': sexual and financial indiscretions, as well as flip-flopping policy decisions which have increased rather than diminished his appeal.

Many indigenous Fijians identify with Rabuka much more easily than they can with the aristocratic Ratu Mara. Counterposed in this way against the elder statesman of Fiji, Rabuka developed his own ethos of popularism and 'can-do' capitalism - exemplified by the National Bank of Fiji debacle. During his Prime Ministership, a brash nouveau riche elite of 'indigenous' Fijians developed and thrived. George Speight is a good representative of this group, but an even better example is his mentor and benefactor Jim Ah Koy: both illustrate a new opportunism in regards to identity politics in Fiji.

A 'general elector' MP in the 1970s, Chinese-Fijian Ah Koy was sent to political coventry by Ratu Mara for insubordination. Concentrating his energies in business during the 1980s, Ah Koy's phenomenal success became worthy of a Horatio Alger story. In the first post-coup election of 1992, however, Ah Koy re-emerged as a political candidate, this time on the indigenous Fijian electoral roll. Although his eligibility to stand as a Fijian was challenged by other indigenous Fijians, Ah Koy won his case 
in court, and has represented his maternal constituency of Kadavu in Parliament ever since.

Like Ah Koy, George Speight's father, a 'part-European' and former general elector named Sam Speight, became a 'born-again Fijian' in the post-coup era. Sam Speight legally changed his name to Savenaca Tokainavo, winning an indigenous Fijian electoral seat in Parliament in the 1992 and subsequent elections.

In Fiji's disconcertingly racialised electoral system (comprising three electoral rolls - Fijian, Indian and General) general voters have historically aligned themselves with indigenous Fijian chiefly interests. The category of general voters covers Fiji's multitude of ethnic minority communities: Banabans, Chinese, Europeans, Gilbertese, 'part-Europeans', Samoans, Solomon Islanders, Tongans and Tuvaluans.

'Part-Europeans' form the largest and most influential group of general voters and in the post-coup era have shifted away from their historical identification with colonial European privilege towards a reclamation of their 'part-Fijian' or vasu-i-taukei roots. This shift in 'part-European' identification reflects a recognition of the contemporary realities of political power in Fiji: indigenous Fijians rule.

George Speight claims to represent indigenous Fijian interests. Sporting his European name, speaking exclusively in English, drawing on his Australian and American degrees in business for mana, and wearing his designer clothes, Speight does indeed represent indigenous Fijian interests. But Speight's indigenous Fijian interests are clearly neither the indigenous Fijian interests of Ratu Mara nor those of the late Dr Bavadra.

Speight's version of indigenous Fijian interests probably coincides in many areas with Rabuka's version of indigenous Fijian interests. But the men Speight has surrounded himself with also represent a changing of the guard from Rabuka's Queen Victoria School old Boys network to an unlikely coalition of relatively young 'old boys' from Marist Brothers High School (Ratu Mara's alma mater) and Suva Grammar School.

And what of Speight et al's relationship with the marching/looting masses who were so inspired by the illegal actions in the House of Parliament on Friday 19 May 2000? It is a relationship of convenience: 
Speight has about as much respect for the 1997 Constitution he once congratulated Professor Brij Lal on, as he does for the indigenous marama in sulu and jaba helping herself to bales of cloth through the shattered window of a Waimanu Road store.

The march was organised by church and Taukei Movement leaders, and though the looting may not have been planned, they certainly enabled it. Looting has become an ominous feature of recent indigenous Fijian responses to crisis: during the floods of 1998, at the tragic crash site of flight PC 121 in 1999, and now in the streets of Suva - 'the millennium city'. The image of a humble, God-fearing, dignified and hospitable people marketed by the Fiji Visitors Bureau is chillingly contraverted. The chiefs and church ministers stir their people but the simple truth is they do not control them: a group of alert and ambitious businessmen has used this feature of Fijian leadership to its advantage. Indigenous Fijians rule, but indigenous Fijians are not united.

This puts the past 12 months of the Mahendra Chaudhry Labour Coalition government's rule in perspective. The government has survived this long because of the backing of Ratu Mara. The government is in crisis right now because other indigenous Fijian groups are challenging Ratu Mara's authority. Rabuka has recently acknowledged this: the real struggle is amongst indigenous Fijians, and it is continually masked by the rhetoric of a racial conflict between indigenous Fijians and Indo-Fijians.

The impoverishment and disaffection of indigenous Fijians are not a result of 12 months of leadership by an Indo-Fijian. It is the result of 30 fraught years of modern indigenous Fijian leadership that have sacrificed the economic and cultural well-being of a people for the advancement of a few.

Speight's ignominious entry into the national and international limelight is but a symptom of the complex contradictions and competing interests facing indigenous Fijian society today. George Speight has not only kidnapped a democratically elected Prime Minister and his Cabinet; he has taken hostage much of the hope and potential Fiji had at the turn of the century to become a nation united. And when the present crisis at Fiji's House of Parliament in Nasese passes, as it inevitably will, the question will remain: what is Fijian nationalism when there is no nation? 